\title{
Perennation of Uncinula necator in Vineyards of Eastern Washington
}

\author{
G. G. Grove, Washington State University Irrigated Agriculture Research and Extension Center, Prosser 99350
}

\begin{abstract}
Grove, G. G. 2004. Perennation of Uncinula necator in vineyards of Eastern Washington. Plant Dis. $88: 242-247$.

Studies on the mode of perennation of Uncinula necator in Eastern Washington were conducted over a 4-year period. Evidence of perennation of $U$. necator in infected dormant buds was not evident during vineyard surveys conducted over the period. Cleistothecia retrieved from bark fissures and senesced leaves contained viable ascospores at bud burst and later. The proportion of cleistothecia retrieved from bark that contained viable ascospores at bud burst ranged from 0.19 to $0.48,0.09$ to $0.72,0.18$ to 0.22 , and 0.48 to 0.67 in $1998,1999,2000$, and 2001 , respectively. Viability of cleistothecia retrieved from senesced leaves in two vineyards at bud burst was 0.41 and 0.40 in 1998 and was 0.5 and 0.4 in 1999. Ascospore release in lab studies occurred from the late-dormant stage through the prebloom and (in some cases) the bloom stages. The initial ascosporic infection of Chardonnay leaves began at the late-dormant stage; colony numbers then declined through the prebloom and bloom stages. In vineyard studies, ascospores were trapped as late as 70 days after bud burst during rain events of 3.9 to $9.6 \mathrm{~mm}$. Detection of ascospores in vineyard air preceded the initial occurrence of powdery mildew symptoms and signs and the occurrence of conidia in volumetric spore traps by several days. Cleistothecia are the only known source of primary inoculum in the grape-production regions of Eastern Washington.
\end{abstract}

Powdery mildew of viniferous grape (Vitis vinifera L.), which is caused by $U n$ cinula necator (Schwein.) Burrill (= Erysiphe necator; 1), is circumglobal in distribution and potentially problematic wherever wine grapes are produced (13). First documented in Eastern Washington in 1982 (10), powdery mildew has become the most serious disease of grape in the region. Severe epidemics occurred in 1995 and 1996 (8) when mildew-induced losses reached 20 to $25 \%$ in susceptible cultivars (e.g., Chardonnay). Those growing seasons were characterized by abnormally high rainfall between bud burst and the immediate postbloom period. For example, in 1995 and 1996, measurable precipitation was recorded on 25 and 27 days, respectively, between 15 April and 1 July; the number of days when precipitation was recorded during this time period in 1985 to 1994 ranged from 7 to 11 . Less severe but

Corresponding author: G. G. Grove

E-mail: grove@wsu.edu

Washington State University Department of Plant Pathology New Series \#0368.

Financial support was provided by the Agricultural Research Center, Washington State University, Pullman, and the Washington Wine Advisory Board.

Accepted for publication 1 October 2003.

Publication no. D-2003-1230-01R

(C) 2004 The American Phytopathological Society significant losses of 5 to $10 \%$ were reported following the more localized epidemics of 1999 and 2000 (9). The disease is a chronic problem in vineyards where over-the-canopy irrigation is used for early-season frost protection or early-season watering.

Since the 1995 epidemic, the disease has been managed through the intensive use of demethylation-inhibiting (DMI) and strobilurin fungicides. Other than preliminary reports, there is no published research information on the source of primary inoculum or epidemiology of the disease in Eastern Washington. As a result, Washington growers have relied on management strategies from other geographical areas (particularly California) or have developed cultural and chemical disease management approaches without consideration of the disease epidemiology or prevailing meteorological conditions. Fungicide applications commence at the late-dormant or flatleaf stages and continue at 10- to 14-day intervals until veraison. During years when powdery mildew epidemics fail to develop or are delayed, this management approach may result in both unnecessary expenses and excessive release of pesticides into the vineyard environment.

Perennation of the fungus can occur in the form of mycelium in dormant infected buds (13) or cleistothecia. It has been assumed that the former mode of perennation was the only means of perennation in Eastern Washington (10). In their landmark 1987 study, Pearson and Gadoury docu- mented the survival of $U$. necator ascocarps in exfoliating bark on New York grapevines (12). Since then, the epidemiological significance of the ascigerous stage has been documented in California (14), Italy (2), France, and Australia (11). The present author observed profuse cleistothecia production in Eastern Washington on infected foliage of several cultivars during the latter stages of the 1995 and 1996 epidemics. Early in the subsequent growing seasons, primary disease distribution patterns consistent with ascosporic infections were observed $(11,13)$. Effective management is based on an understanding of the epidemiology of the disease, including the mode of perennation. The purpose of this study was to determine the source of primary inoculum for grape powdery mildew epidemics in Eastern Washington. The present work was outlined in an earlier publication (7).

\section{MATERIALS AND METHODS}

Vineyard surveys. Surveys of 17, 5, and 3 Vitis vinifera L. vineyards (cvs. Chardonnay, Lemberger, and Cabernet Sauvignon, respectively) in the Columbia and Yakima Valleys, containing a total of about 50,000 vines, were conducted from bud burst through bunch closure during each year from 1997 to 2001. All vineyards had severe powdery mildew infestations during the 1995-97 growing seasons and were located within a $50-\mathrm{km}$ radius of Prosser, WA. Vineyards were inspected weekly for flag shoots and other evidence for point sources of primary inoculum (13). One hundred vines each in Chardonnay, Lemberger, and Cabernet Sauvignon vineyards located at the Washington State University Irrigated Agriculture Research and Extension Center (WSU-IAREC) also were included in the surveys. All WSUIAREC vineyards had histories of severe powdery mildew epidemics.

Ascocarp viability. Exfoliating bark. In 1998, four commercial vineyards (cv. Chardonnay) were studied. Several vineyards comprising cvs. Lemberger, Chardonnay, or Cabernet Sauvignon were used for the 1999 to 2001 portions of the study. Most vineyards used in the 1999 to 2001 survey were located at WSU-IAREC, with the exception of one commercial Chardonnay vineyard located about $7 \mathrm{~km}$ northwest of Prosser, WA. Severe powdery mildew epidemics occurred in all test vineyards during 1997 and the subsequent years of 
the study. All vines were self-rooted and vineyards ranged in age from 5 to 25 years. During the mid- to late-dormant period through $0.5-\mathrm{cm}$-diameter berry stage, exfoliating bark samples were taken from the cordons at monthly intervals. At each sampling date, about $100 \mathrm{~g}$ of bark was removed from the cordon-trunk interface of each of four vines that were selected arbitrarily. Samples were bulked in a 4-liter plastic bag and stored at $3^{\circ} \mathrm{C}$ until processing. Samples were mixed thoroughly by hand and by subsequent vigorous shaking. About $100 \mathrm{~g}$ of the bulked sample was placed into a 4-liter Erlenmeyer flask containing 1.5 liters of crushed ice and 1 liter of sterile distilled water and shaken vigorously by hand for $3 \mathrm{~min}$. The resultant suspension was poured through nested sieves (5.0-, 0.12-, and 0.073-mm mesh). The bottom sieve was removed and the debris washed to one side using tap water. The debris were resuspended in $100 \mathrm{ml}$ of sterile distilled water in a graduated cylinder, shaken vigorously for $1 \mathrm{~min}$, and then poured into a $400-\mathrm{ml}$ beaker. The graduated cylinder was rinsed with $50 \mathrm{ml}$ of sterile distilled water that was added to the suspension, bringing the total volume to $150 \mathrm{ml}$. A stir bar was added to the beaker and the suspension was agitated for $5 \mathrm{~min}$. Five 10-ml aliquots were removed from the suspension and each aliquot poured over individual 70-mm-diameter pieces of \#2 Whatman filter paper. Using a dissection microscope and needle forceps, about 100 ascocarps were removed from the five pieces of filter paper and transferred to glass microscope slides. Ascospore viability was assessed using the methods of Pearson and Gadoury (12) during the 1998 portion of the study and Cortesi et al. (3) during the subsequent years. Cleistothecia were considered viable if they contained any viable ascospores.

Senesced leaves. Ascocarp perennation was studied on senesced leaves of severely infested cv. Lemberger in 1998 and cvs.

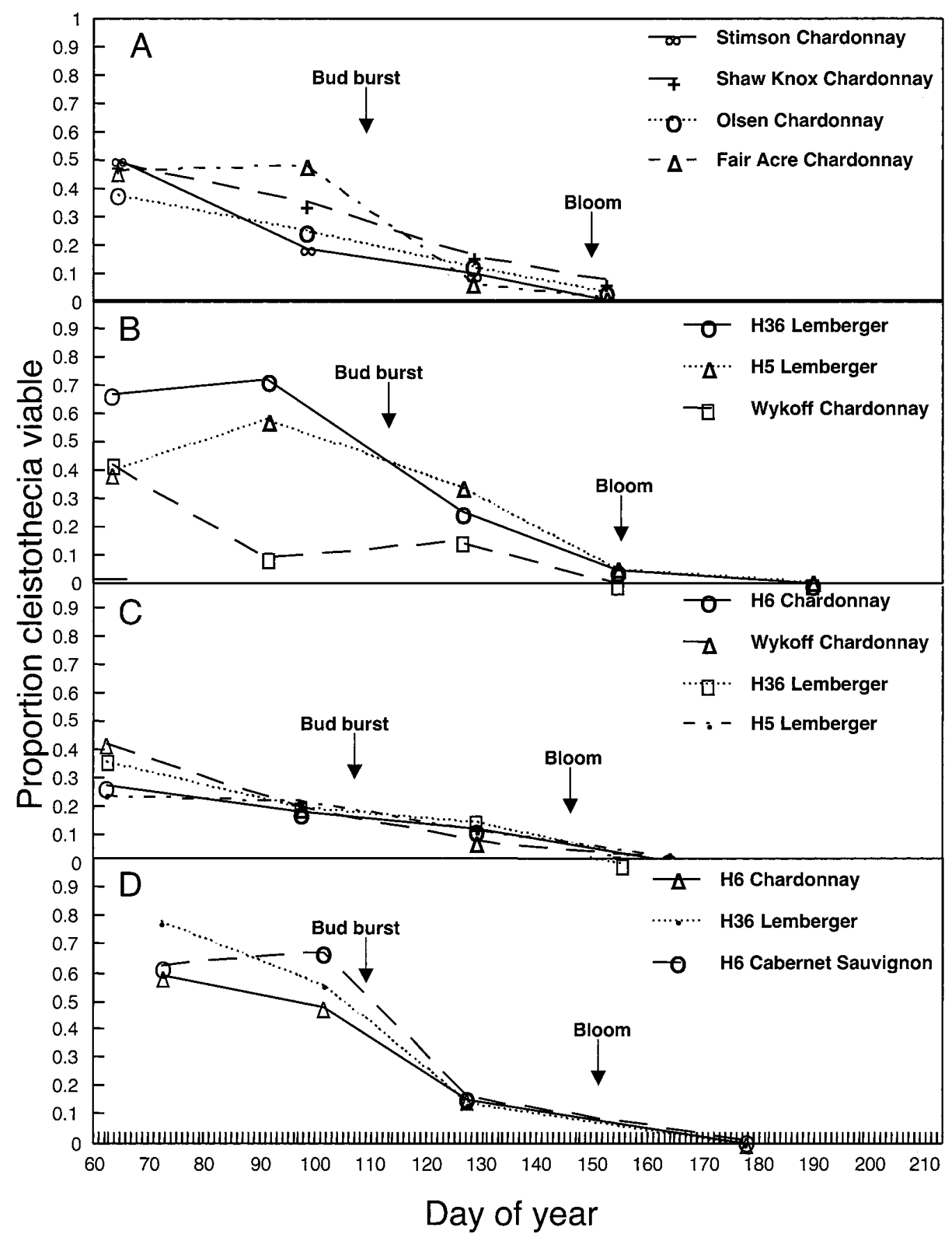

Fig. 1. Viability of cleistothecia of Uncinula necator retrieved from bark of grapevines near Prosser, WA, in A, 1998, B, 1999, C, 2000 , and D, 2001. 
Lemberger and Cabernet Sauvignon in 1999. Immediately prior to leaf fall, 100 infected leaves were selected from severely diseased vines and placed in rectangular wire cages 1 by 0.5 by $0.5 \mathrm{~m}$ in size (length by width by height) constructed from $0.63-\mathrm{cm}-\mathrm{mesh}$ chicken wire. Cages were positioned on the floor of the vineyards. Beginning about 1 month prior to bud break and continuing at monthly intervals through fruit set, 10 leaves per sampling date were selected and removed from the cage and placed in 3.8-liter Ziplock bags. Samples were stored at $2^{\circ} \mathrm{C}$ until processing. Leaves were washed over filter paper contained in a Buchner funnel using $100 \mathrm{ml}$ of sterile distilled water delivered using a small squirt bottle. Disks were examined using a dissection scope and about 100 ascocarps were transferred to glass slides for viability assessment as described above.

Ascospore release. Ascospore release and leaf infection studies were conducted using separate bark samples removed at each sampling date from all vineyard sites. Ascospore release from ascocarps overwintered on senesced leaves was studied at one site. About 25 cleistothecia from each bark sample were transferred from the aforementioned filter paper disks onto clean filter paper disks attached to a petri plate top using a thin layer of silicon grease. Four replications per vineyard site were used at each sampling date. Disks were gently misted with about $1 \mathrm{ml}$ of sterile distilled water using a surgeon's atomizer. Cleistothecia were inverted over glass microscope slides situated atop a glass rod positioned in the petri plate bottom. Plates were sealed with Parafilm and incubated for $24 \mathrm{~h}$ at $21^{\circ} \mathrm{C}$ in darkness. After the incubation period, slides were removed from petri plates, stained with acid fuchsin, and covered with coverslips. The number of ascospores released was determined by microscopic examination.

Leaf infection. At each sampling date, filter paper disks containing about 25 cleistothecia each were moistened with sterile distilled water using a surgeon's atomizer. Disks were immediately attached (with the side bearing cleistothecia facing downward) to the inside of a glass petri plate top using a thin layer of silicone grease. Disks were inverted over individual immature but fully expanded leaves of cv. Chardonnay (abaxial leaf surface facing upward) on a glass triangle situated on the bottom of a glass petri plate containing $5 \mathrm{ml}$ of sterile distilled water. After $8 \mathrm{~h}$ at $25^{\circ} \mathrm{C}$, the disks were removed and leaves were incubated for 10 days at $24^{\circ} \mathrm{C}$ with a $16-\mathrm{h}$ photoperiod. At the conclusion of the incubation period, the number of powdery mildew colonies per leaf was determined by examination at $\times 20$. Ten replicate leaves were inoculated using cleistothecia collected from each vineyard at each sampling date. Leaves incubated in the absence of filter paper disks and cleistothecia served as controls.
Vineyard spore trapping. During the 1998 to 2001 growing seasons, a Burkhard volumetric spore trap was placed in a 30year-old WSU-IAREC Lemberger vineyard with a history of severe powdery mildew infestations. The trap was operated continuously from about 2 weeks prior to bud burst until harvest. The trap was adjusted to sample air at about 10 liters/min. Trapping tapes were removed from the trap at weekly intervals, dissected into segments corresponding to periods of $24 \mathrm{~h}$ $(0000$ to $2359 \mathrm{~h})$, mounted in acid fuchsin on glass slides, and examined at $\times 200$. The number of ascospores and conidia of $U$. necator was recorded. A CR-21X (Campbell Scientific, Logan, UT) datalogger positioned $5 \mathrm{~m}$ from the trap provided continuous records of temperature, relative humidity, rainfall, leaf wetness duration, wind speed, wind direction, and solar radiation. The foliage and fruit of vines was inspected daily for symptoms and signs of powdery mildew.

\section{RESULTS}

Vineyard surveys. Flag shoots, as indicators of bud perennation of $U$. necator, were not found in any vineyards during the surveys. Powdery mildew was present in all vineyards surveyed during each year of the study. The initial signs of powdery mildew were discrete colonies on the abaxial surfaces of leaves positioned close to exfoliating bark of heads and cordons. The spatial distribution of primary mildew

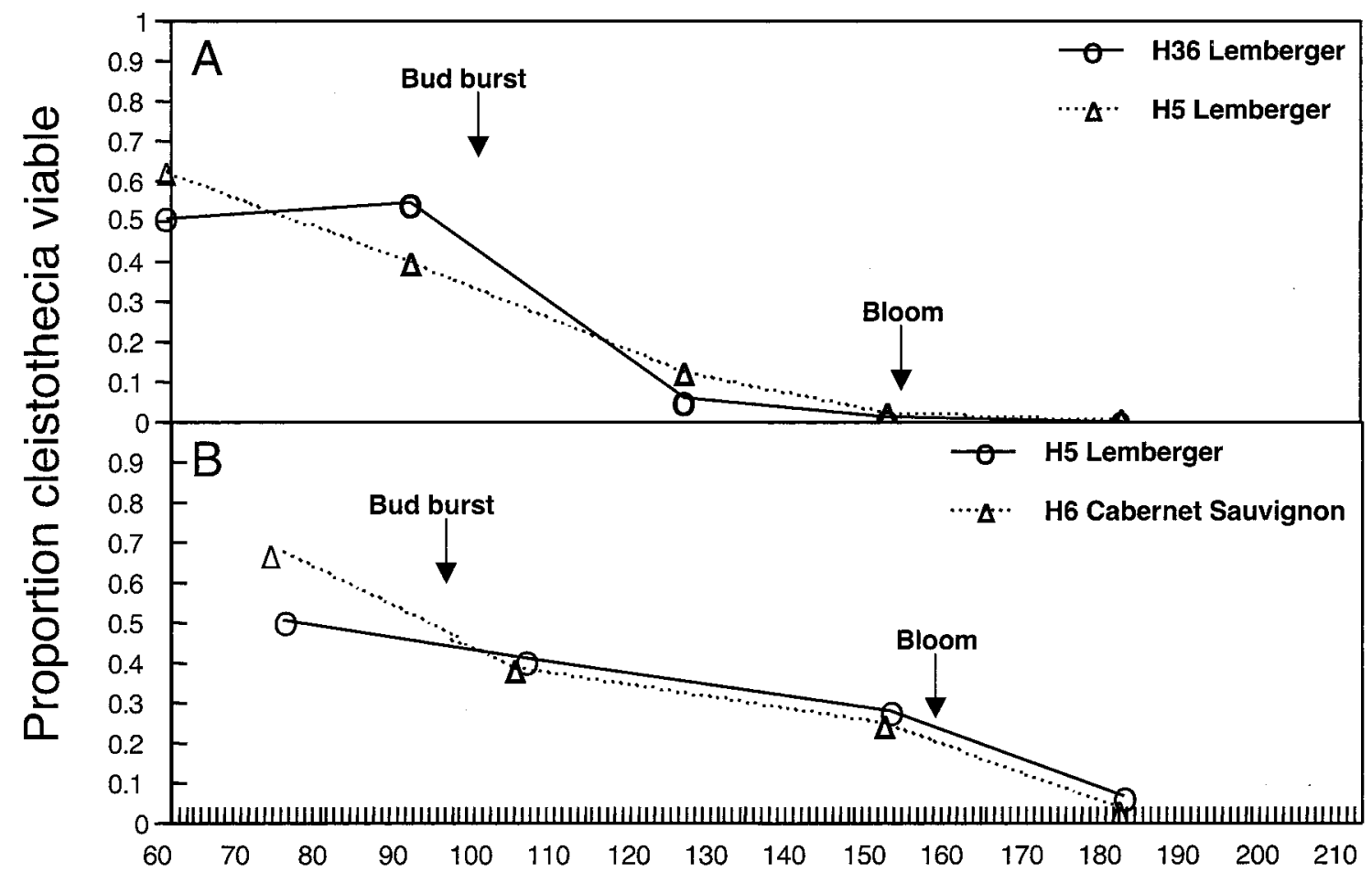

\section{Day of year}

Fig. 2. Viability of cleistothecia of Uncinula necator retrieved from leaves of grapevines (cv. Lemberger) overwintered on the vineyard floor in A, 1998 and B, 1999. 
colonies appeared to be random and not in discrete foci, as would be expected with bud perennation.

Ascocarp viability. Ascocarps in bark survived winter and persisted through bloom during all years of the study (Fig. 1). The proportion of cleistothecia viable at or near bud burst ranged from 0.09 to 0.67 over the course of the 4-year study. Viability immediately before or shortly after bloom ranged from 0 to 0.08 during the study. Viability (at bud burst) of cleistothecia overwintered on leaves (Fig. 2) averaged 0.4 and 0.48 in 1998 and 1999 , respectively.

Ascospore release. Ascospore release occurred from the late-dormant through bloom periods during all years of the study. The average number of ascospores released per 100 cleistothecia retrieved from bark and senesced leaves at or near bud burst ranged from 241 to 925 and 224 to 447 , respectively, over the course of the study. Release at or shortly after bloom averaged ranged from 20 to 100.5 and 120 to 140 , respectively. For ease of temporal interpretation, the cumulative proportion of ascospores (12) released from ascocarps retrieved from bark and senesced leaves are presented in Figures 3 and 4, respectively.

Leaf inoculations. Throughout the study, leaf infection occurred from about 1 month prior to bud burst through prebloom or bloom stages (Tables 1 and 2). The total number of colonies resulting from inoculations using cleistothecia retrieved from bark or senesced leaves was highest at or near bud burst and then declined. However, infection as late as the immediate prebloom or bloom periods resulted from inoculations using both ascocarp sources.

Vineyard spore trapping. Totals of 41 , 23, 16, and 10 ascospores were trapped between bud burst and bloom during the 1998 to 2001 growing seasons, respectively. Ascospores were trapped as late as 49, 31, 53, and 70 days after bud burst during the respective years of the study. Ascospores were trapped only during periods of rainfall (3.9 to $9.7 \mathrm{~mm}$ ) that occurred between bud burst and (in one case) the immediate postbloom period. The initial powdery mildew signs were always observed at least 7 days after the initial trapping of ascospores. Symptoms were evident several days before the initial detection of conidia by the volumetric spore traps. The spatial distribution of primary mildew was random.

\section{DISCUSSION}

Flag shoots and other evidence of point inoculum sources were not observed during vineyard surveys. Viable ascocarps retrieved from exfoliating bark and senesced leaves persisted through the prebloom or immediate postbloom periods. Ascospores were trapped from the vineyard air during all years of the study and

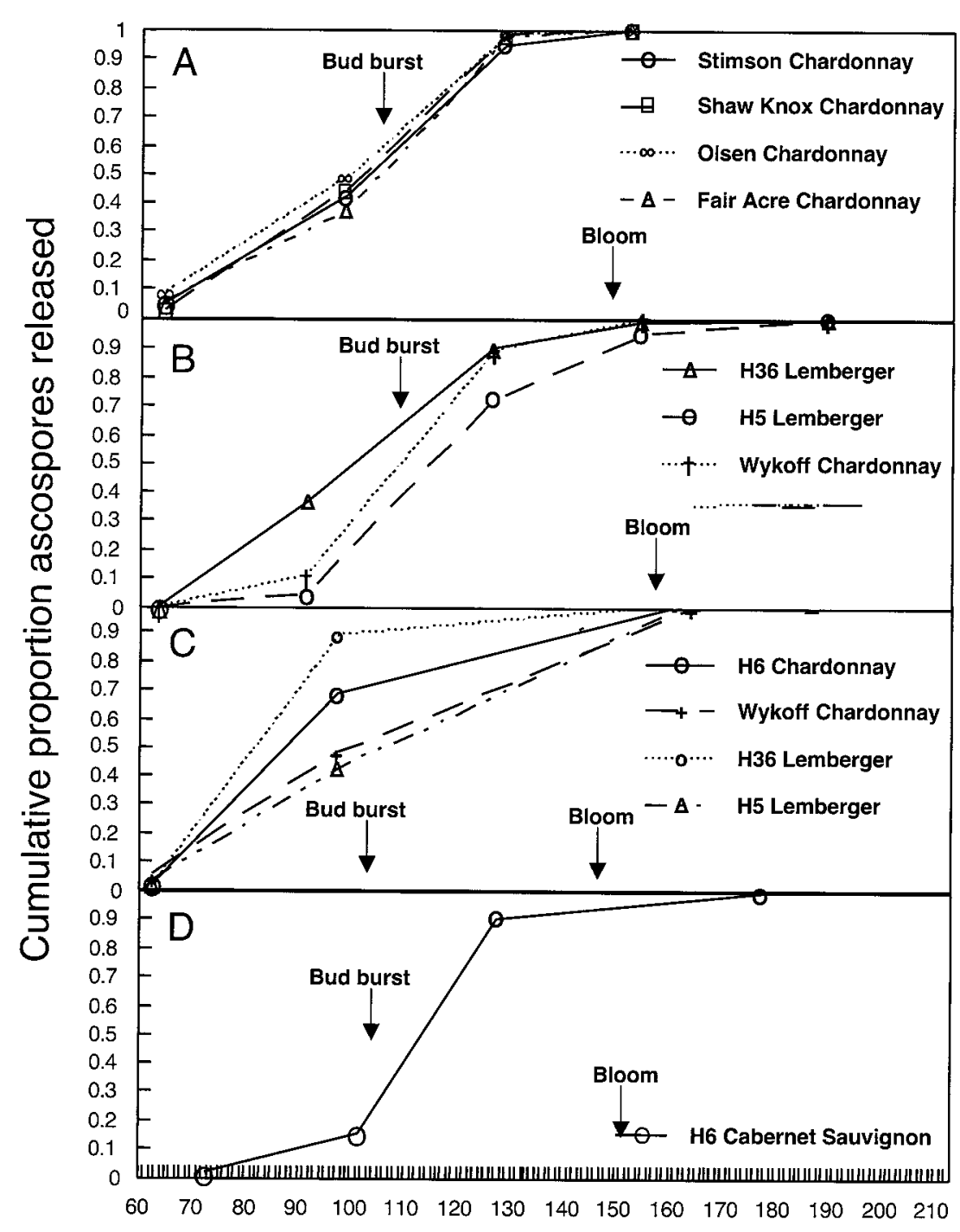

Day of year

Fig. 3. Cumulative proportion of ascospores released from overwintered cleistothecia of Uncinula necator harvested from exfoliating bark of grapevines near Prosser, WA in A, 1998, B, 1999, C, 2000, and D, 2001.

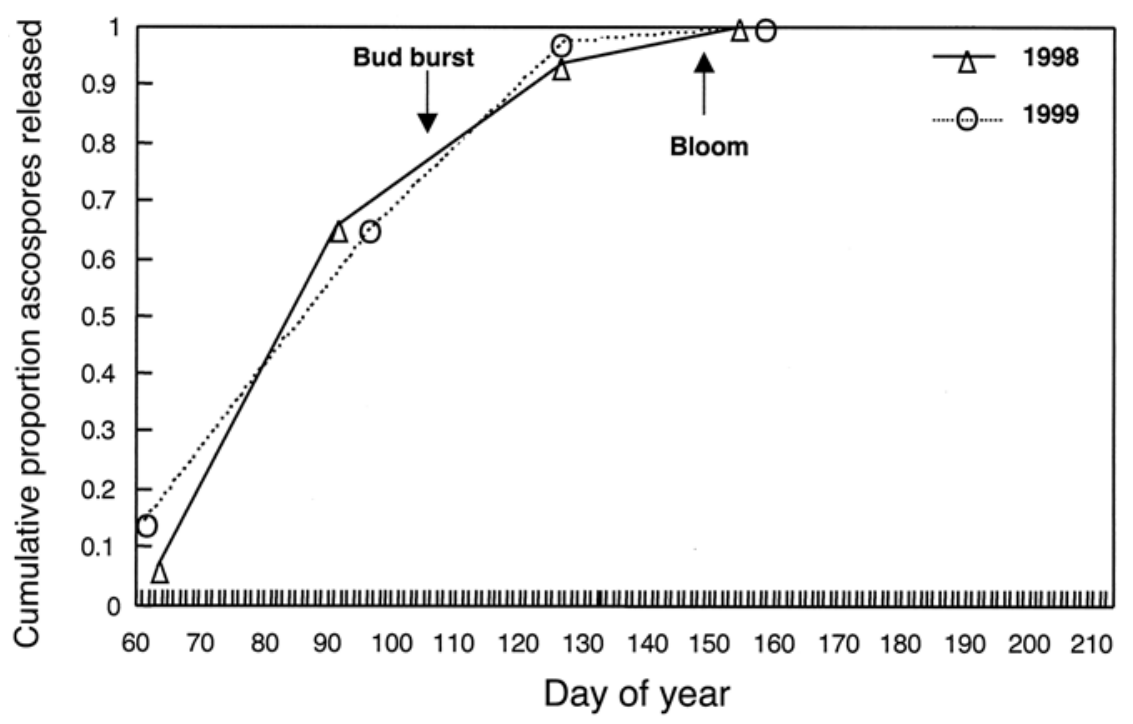

Fig. 4. Cumulative proportion of ascospores released from overwintered cleistothecia of Uncinula necator harvested from senesced grape leaves stored in vineyards near Prosser, WA, 1997-98 and 1998-99. 
their occurrence preceded the appearance of vineyard symptoms and detection of conidia by volumetric spore traps. The first powdery mildew colonies were distributed randomly throughout the vineyard and located on the abaxial surfaces of leaves in close proximity to bark. This comprehensive body of evidence indicates that cleistothecia are the only known source of primary inoculum for grape powdery mildew epidemics in Eastern Washington.

Cleistothecia are considered the sole or important sources of primary inoculum in New York $(4,5,13)$, parts of California (14), Italy (2), Australia (11), and now in the arid production region of Eastern Washington. As in Australia (11) and Italy (2) and unlike New York (4), cleistothecia also survived on senesced leaves on the vineyard floor. The demonstration of the importance of this stage in Eastern Washington is further evidence for the importance of the ascigerous stage in the epidemiology of grape powdery mildew in temperate regions. The epidemiological significance of cleistothecia in exfoliating grape bark has been documented by others (2,4-6,11). However, the significance of ascocarp survival on senesced leaves on the vineyard floor in Eastern Washington is unclear. Abundant viable cleistothecia in leaf litter may serve as an important second source of primary inoculum. Perennation on leaves may be important if autumn rains are insufficient to disperse cleistothecia to bark (4) or in young vineyards with low amounts of exfoliating bark. Conversely, the experimental methods (storing leaves in cages) used to study perennation on the vineyard floor did not parallel the fate of senesced leaves in the region's vineyards. The viticulture areas of Eastern Washington are characterized by frequent high winds during the fall and winter months, resulting in distribution of much of the vineyard leaf litter outside of the vineyard. Furthermore, Washington growers typically plant graminaceous cover crops in the autumn and mow or mulch vineyards after late-winter pruning operations. The former practice results in the incorporation of some remaining leaf litter into the vineyard soil, which would adversely affect ascocarp survival (4). The extreme fragmentation of leaves resulting from the latter practices also could affect ascocarp viability on leaf fragments by accelerating tissue decomposition. Autumn dispersal $(2,4)$ of cleistothecia from points of origin to substrates more protected from the wind (e.g., bark) and cultural practices probably ensure the availability of primary

Table 2. Ascosporic infection of grapevine (cv. Chardonnay) leaves after inoculation with overwintered cleistothecia of Uncinula necator ${ }^{\mathrm{a}}$

\begin{tabular}{lllcc}
\hline & & \multicolumn{3}{c}{$\begin{array}{c}\text { Total no. of mildew colonies } \\
\text { (per 10 leaves) per vineyard and cultivar }\end{array}$} \\
\cline { 3 - 5 } Year, day & \multicolumn{1}{c}{ Stage } & H 36 Lemberger & H5 Lemberger & H6 Cabernet Sauvignon \\
\hline 1998 & & & & \\
67 & Late dormant & 13 & 8 & $\ldots$ \\
98 & Bud burst & 16 & 9 & $\ldots$ \\
121 & 15-cm shoots & 4 & 7 & $\ldots$ \\
152 & Prebloom & 1 & 2 & 7 \\
1999 & & & & 19 \\
63 & Late dormant & $\ldots$ & 9 & 1 \\
91 & Bud burst & $\ldots$ & 3 & $\ldots$ \\
154 & Prebloom & $\ldots$ & 3 & \\
\hline
\end{tabular}

${ }^{a}$ Leaves were inoculated with cleistothecia retrieved from senesced leaves that were overwintered on the vineyard floor beginning at the late dormant stage. inoculum at the beginning of the subsequent growing season.

Other cultural and disease-management practices used in Eastern Washington may require modification now that the mode of perennation and source of primary inoculum is known. Over-the-trellis lime sulfur applications designed to reduce overwintered inoculum and delay epidemic onset are used routinely in regions of the Western United States where ascigerous perennation occurs. The presence of a functional teleomorph in Washington recently has prompted some local growers to adopt the practice. Perennation of ascocarps also may occur on senesced leaves on the vineyard floor in this region; therefore, it is highly unlikely that such applications as currently practiced would eliminate the primary inoculum source entirely. Furthermore, Gadoury et al. (6) also reported that this management practice delayed epi-

Table 1. Ascosporic infection of grapevine (cv. Chardonnay) leaves after inoculation with overwintered cleistothecia of Uncinula necator retrieved from four vineyards in Eastern Washington ${ }^{\mathrm{a}}$

\begin{tabular}{|c|c|c|c|c|c|c|c|c|c|c|}
\hline \multirow[b]{3}{*}{ Year, day } & \multirow[b]{3}{*}{ Stage } & \multicolumn{9}{|c|}{ Total no. of mildew colonies (per 10 leaves) per cultivar and vineyard } \\
\hline & & \multicolumn{6}{|c|}{ Chardonnay } & \multicolumn{2}{|c|}{ Lemberger } & \multirow{2}{*}{$\begin{array}{c}\text { Cabernet Sauvignon } \\
\text { H6 }\end{array}$} \\
\hline & & Stimson & Shaw & Olsen & Fair Acre & Wykoff & H6 & H36 & H5 & \\
\hline \multicolumn{11}{|l|}{$1998^{b}$} \\
\hline 67 & Dormant & 13 & 12 & 10 & 12 & $\ldots$ & $\ldots$ & $\ldots$ & $\ldots$ & $\ldots$ \\
\hline 98 & Bud burst & 5 & 9 & 6 & 12 & $\ldots$ & $\ldots$ & $\ldots$ & $\ldots$ & $\ldots$ \\
\hline 121 & $15-\mathrm{cm}$ shoots & 3 & 4 & 3 & 2 & $\ldots$ & $\ldots$ & $\ldots$ & $\ldots$ & $\ldots$ \\
\hline 152 & Prebloom & 1 & 2 & 1 & 1 & $\ldots$ & $\ldots$ & $\ldots$ & $\ldots$ & $\ldots$ \\
\hline \multicolumn{11}{|l|}{1999} \\
\hline 63 & Dormant & $\ldots$ & $\ldots$ & $\ldots$ & $\ldots$ & 11 & $\ldots$ & 17 & 10 & $\ldots$ \\
\hline 91 & Bud burst & $\ldots$ & $\ldots$ & $\ldots$ & $\ldots$ & 2 & $\ldots$ & 18 & 15 & $\ldots$ \\
\hline 126 & $15-\mathrm{cm}$ shoots & $\ldots$ & $\ldots$ & $\ldots$ & $\ldots$ & 4 & $\ldots$ & 6 & 9 & $\ldots$ \\
\hline 154 & Prebloom & $\ldots$ & $\ldots$ & $\ldots$ & $\ldots$ & 0 & $\ldots$ & 1 & 1 & $\ldots$ \\
\hline 189 & 0.2 -cm-diameter berries & $\ldots$ & $\ldots$ & $\ldots$ & $\ldots$ & 0 & $\ldots$ & 0 & 1 & $\ldots$ \\
\hline \multicolumn{11}{|l|}{2000} \\
\hline 61 & Dormant & $\ldots$ & $\ldots$ & $\ldots$ & $\ldots$ & 7 & 11 & 9 & 6 & $\ldots$ \\
\hline 96 & Bud burst & $\ldots$ & $\ldots$ & $\ldots$ & $\ldots$ & 5 & 5 & 5 & 6 & $\ldots$ \\
\hline 126 & $15-\mathrm{cm}$ shoots & $\ldots$ & $\ldots$ & $\ldots$ & $\ldots$ & 5 & 5 & 6 & 4 & $\ldots$ \\
\hline 158 & Prebloom & $\ldots$ & $\ldots$ & $\ldots$ & $\ldots$ & 3 & 2 & 4 & 3 & $\ldots$ \\
\hline 189 & 0.6-cm-diameter berries & $\ldots$ & $\ldots$ & $\ldots$ & $\ldots$ & 1 & 1 & 1 & 1 & $\ldots$ \\
\hline \multicolumn{11}{|c|}{ 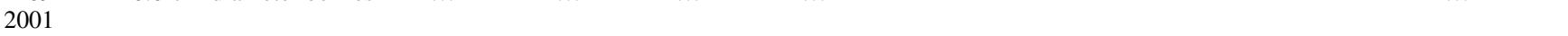 } \\
\hline 72 & Dormant & $\ldots$ & $\ldots$ & $\ldots$ & $\ldots$ & $\ldots$ & 15 & 20 & $\ldots$ & 16 \\
\hline 101 & Bud burst & $\ldots$ & $\ldots$ & $\ldots$ & $\ldots$ & $\ldots$ & 12 & 14 & $\ldots$ & 17 \\
\hline 127 & $15-\mathrm{cm}$ shoots & $\ldots$ & $\ldots$ & $\ldots$ & $\ldots$ & $\ldots$ & 4 & 4 & $\ldots$ & 3 \\
\hline 177 & Late bloom & $\ldots$ & $\ldots$ & $\ldots$ & $\ldots$ & $\ldots$ & 0 & 0 & $\ldots$ & 1 \\
\hline
\end{tabular}

${ }^{\text {a }}$ Leaves were inoculated with cleistothecia retrieved from bark of grapevines beginning at the late-dormant stage.

b The only cultivar sampled in 1998 was Chardonnay. 
demic onset only when lime sulfur was applied at 336 liters/ha. This rate is above the maximum legal rate specified on the product labels. Growers should be cognizant of the epidemiology of the disease in the region before using the product as an inoculum eradicant. Over-the-canopy irrigation is used for frost protection and general irrigation in some vineyards of Eastern Washington. At temperatures above $10^{\circ} \mathrm{C}$, this practice could provide the wetting necessary for ascospore release (12) and primary infection (5). As a result, over-thecanopy irrigation after bud burst and prior to the seasonal exhaustion of the ascospore supply should be discouraged. This also may account for the increased incidence and severity of powdery mildew in vineyards where the practice commonly is used early in the growing season. Conversely, if utilized prior to bud burst, this irrigation method may provide a means of artificially stimulating ascospore release and depletion of the primary inoculum supply.

The presence of a functional ascigerous stage and apparent absence of bud perennation raise additional questions about disease management in the region. Prior to these studies, growers assumed that airborne inoculum was available at bud burst and, even in the absence of wetness, disease onset began shortly thereafter. The demonstration of cleistothecia as the primary inoculum source indicates that wetting is necessary for epidemic initiation and that growers possibly could reduce the number of fungicide applications through the consideration of early-season climatic conditions. Our findings indicate that initiating fungicide applications at the first emergence of green tissue may be unnecessary if the wetting requirement for ascospore release has not been met. These findings could be particularly important during years with no rain events, or with rainfall or overhead irrigation insufficient for ascospore release and primary infection.

\section{ACKNOWLEDGMENTS}

I thank G. Davis and R. Boal for technical assistance.

\section{LITERATURE CITED}

1. Braun, U., and Takamatsu, S. 2000. Phylogeny of Erysiphe, Microsphaera, Uncinula (Erysipheae) and Cystotheca, Podosphaera, Sphaerotheca (Cystotheceae) inferred from rDNA ITS sequences-some taxonomic consequences. Schlechtendalia 4:1-33.

2. Cortesi, P., Baslach, M., Ricciolini, M., and Gadoury, D. M. 1997. Cleistothecia of Uncinula necator-an additional source of inoculum in Italian vineyards. Plant Dis. 81(8):922926.

3. Cortesi, P., Gadoury, D. M., Seem, R. C., and Pearson, R. C. 1995. Distribution and retention of cleistothecia of Uncinula necator on the bark of grapevine. Plant Dis. 79:15-19.

4. Gadoury, D. M., and Pearson, R. C. 1988. Initiation, development, dispersal, and survival of cleistothecia of Uncinula necator in New York vineyards. Phytopathology 78:14131421.

5. Gadoury, D. M., and Pearson, R. C. 1990.
Germination of ascospores and infection of $\mathrm{Vi}$ tis by Uncinula necator. Phytopathology 80:1198-1203.

6. Gadoury, D. M., Pearson, R. C., Riegel, D. G., Seem, R. C., Becker, C. M., and Pscheidt, J. W. 1994. Reduction of powdery mildew and other diseases by over-the-trellis applications to dormant grapevines. Plant Dis. 78:83-87.

7. Grove, G. G., Davis, G. H., and Boal, R. J. 1999. Powdery mildew of grape: Perennation of Uncinula necator in Eastern Washington. (Abstr.) Phytopathology 89:S30.

8. Grove, G. G., and Watson, J. 1996. Washington researchers attack powdery mildew. Good Fruit Grow. 48(5):27-32.

9. Grove, G. G., and Watson, J. 2000. Powdery mildew: Local insights into eastern Washington's primary grape disease. Good Fruit Grow. 52(12):65-70

10. Johnson, D. A., and Ahmedulla, M. 1983 Powdery mildew of grapes in Washington. Wash. State Univ. Coop. Ext. Bull. EB1202.

11. Magarey, P. A., Gadoury, D. M., Emmett, R. W., Biggins, L. T., Clarke, K., Wicks, T. J., an Seem, R. C. 1997. Cleistothecia of Uncinula necator in Australia. Vitic. Enol. Sci. 50:210218.

12. Pearson, R. C., and Gadoury, D. M. 1987. Cleistothecia, the source of primary inoculum for grape powdery mildew in New York. Phytopathology 77(11):1509-1514.

13. Pearson, R. C., and Goheen, A. C. 1988. Compendium of Grape Diseases. American Phytopathological Society Press, St. Paul, MN.

14. Stapleton, J. J., Gubler, W. D., Fogle, D. Chellemi, D., Bettiga, L., Leavitt, G., Verdegaal, P., Smith R., and Kelley, K. 1988. Relationships among climate, primary inoculum source, dormant and post emergence control sprays, and grape powdery mildew in California. (Abstr.) Phytopathology 78:1531. 